\title{
Frequent burning in chir pine forests, Uttarakhand, India
}

\author{
Peter Z. Fulé ${ }^{*} \mathbb{D}$, Satish C. Garkoti ${ }^{2}$ and Rajeev L. Semwal ${ }^{3}$
}

\begin{abstract}
Background: Subtropical coniferous forests of the lesser Himalaya provide critical ecosystem services but fire regimes have received limited scientific attention. We reconstructed fire regimes using tree-ring methods in a chir pine (Pinus roxburghii Sarg.) forest of Uttarakhand, India. We cross-dated tree-ring samples with fire scars from 36 trees at three sites near rural villages between 1535 and 1848 m elevation.

Results: Fires were highly frequent (mean fire intervals all $<6 \mathrm{yr}$ ) but of low severity, so most mature trees of this thick-barked species survived numerous burns. Fire scars occurred primarily in the dormant period to the middle of early wood formation in tree-rings, consistent with fire season records. Despite the high fire frequency, fires were mostly asynchronous among the three sites, indicating a bottom-up pattern of local ignitions. We observed that resin tapping of the pines interacted with surface fire by allowing fire to burn into the wood of some tapped trees and weaken their structural integrity to the point of breakage.

Conclusions: Ongoing frequent surface fire regimes linked to human land use are prominent disturbance factors in chir pine forests. Given that these forests support substantial human populations and form part of the watershed for many more people, the effects of anthropogenic fire and interactions with resin-tapping merit further investigation at landscape to regional scales. We suggest developing a research network in Himalayan forests as well as more broadly across southeast Asian pine forests to track interacting disturbances and their ecological and social implications.
\end{abstract}

Keywords: dendrochronology, fire regime, fire scar, Himalaya, Pinus roxburghii, resin tapping, rural

\section{Resumen}

Antecedentes: Los bosques de coníferas subtropicales del bajo Himalaya proveen servicios ecosistémicos críticos, aunque los regímenes de fuego han recibido una limitada atención científica. Reconstruimos los regímenes de fuego usando métodos de conteo de anillos de crecimiento en un bosque de pino de hoja larga del Himalaya (Pinus roxburghii Sarg.) en Uttarakhand, India. Cruzamos datos de muestras de anillos de crecimiento con cicatrices de fuego en 36 pinos en tres sitios cercanos a villorrios rurales con una elevación de entre 1535 y 1848 msnm.

\footnotetext{
* Correspondence: Pete.fule@nau.edu

${ }^{1}$ School of Forestry, Northern Arizona University, P.O. Box 15018, Flagstaff,

Arizona 86011, USA

Full list of author information is available at the end of the article
}

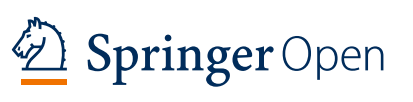

(c) The Author(s). 2021 Open Access This article is licensed under a Creative Commons Attribution 4.0 International License, which permits use, sharing, adaptation, distribution and reproduction in any medium or format, as long as you give appropriate credit to the original author(s) and the source, provide a link to the Creative Commons licence, and indicate if changes were made. The images or other third party material in this article are included in the article's Creative Commons licence, unless indicated otherwise in a credit line to the material. If material is not included in the article's Creative Commons licence and your intended use is not permitted by statutory regulation or exceeds the permitted use, you will need to obtain permission directly from the copyright holder. To view a copy of this licence, visit http://creativecommons.org/licenses/by/4.0/. 
Resultados: Los fuegos fueron altamente frecuentes (todos los intervalos medios de fuego < 6 años) pero de baja severidad, por lo que la mayoría de los árboles maduros de esta especie de corteza gruesa sobrevivieron a numerosos fuegos. Las cicatrices de fuego ocurrieron primariamente en el período de dormición y hasta la mitad de la formación de la madera en los anillos, consistente con los registros estacionales de fuegos. A pesar de la alta frecuencia de fuegos, estos fueron asincrónicos entre los tres sitios, indicando un patrón de igniciones del tipo de abajo hacia arriba (bottom-up). Observamos que la resina que aflora de los pinos interactúa con el fuego superficial permitiendo que el fuego queme la madera de algunos pinos en los lugares con resina acumulada, debilitándolos en su integridad estructural al punto de poder quebrarse.

Conclusiones: Los continuos y frecuentes regímenes de fuegos superficiales ligados al uso humano de la tierra son factores de disturbios prominentes en bosques de pinos de hoja larga del Himalaya. Dado que estos bosques sostienen poblaciones humanas sustanciales y forman parte de una cuenca para mucha más gente, los efectos de los fuegos antropogénicos y las interacciones con la colección de resinas amerita más investigaciones a niveles de paisaje y regional. Sugerimos desarrollar una red científica en los bosques de Himalaya y también más amplia a través de bosques de pinos del sudeste asiático para monitorear la interacción entre disturbios y sus implicancias ecológicas y sociales.

\section{Background}

Global attention has properly focused on the threat to rare or endangered species from climate warming, overexploitation, and increasingly severe disturbances, but widespread species that form the foundation (sensu Ellison 2019) of vast ecosystems may also be vulnerable to loss. The middle elevations of the Himalayan Mountains, home to dense human populations and critical watersheds for far more people, are dominated by chir pine (Pinus roxburghii Sarg.), a species deeply linked to anthropogenic fire disturbance (Singh et al. 2016; Sannigrahi et al. 2020). Although subtropical coniferous forests of the lesser Himalaya provide critical ecosystem services, quantitative assessments of fire regimes and their links with human activity and climate have received limited scientific attention.

Chir pine is found in the Indian states of Jammu and Kashmir, Himachal Pradesh, Uttarakhand, Darjeeling in West Bengal, and Arunachal Pradesh, as well as neighboring Himalayan nations. The highest proportion of forest cover provided by chir pine is in Uttarakhand (Forest Survey of India 2019). In the western Himalaya, it grows in lesser Himalayan ranges, Siwaliks, and in the valleys of the rivers between 450 and 1800 meters above sea level (masl), occasionally up to 2300 masl (Troup 1921; Singh and Singh 1992), while in eastern India, chir pine seldom grows above 1000 masl.

Chir pine has numerous ecological, economic, and cultural values. It is used for timber, fuelwood, boxes for packing horticultural produce, charcoal, dye, herbicide, ink, and resin. Resin extraction from pine species is an internationally important economic activity, with India among the top resin producing nations (Cunningham 2012). The latest available data on resin collection indicated that an annual total of 19.3 million kilograms of resin were collected from the forests of Uttarakhand for industrial extraction of essential oils, turpentine, and rosin (Negi 2019). For local people of the state, although chir pine is not the most preferred timber tree, it is valued as a source of torchwood, fuel, bark for fuelling traditional furnaces of blacksmiths, leaves for broom making and sometimes as thatch, and most importantly, leaf litter for livestock bedding to be mixed into farmyard manure (Negi and Semwal 2010). Resinous heartwood, called dalli in some localities, was traditionally cut up into candle-like sticks (chchilka) and used for igniting fires in hearths and lighting rooms. Local people consider chir pine a sacred species; its large, green branches are brought home for performing rituals during traditional weddings and other ceremonies.

Chir pine trees can grow large, reaching 30 to $50 \mathrm{~m}$ in height with a trunk diameter that can exceed $2 \mathrm{~m}$. Kumar et al. (2013) reported total carbon stock of chir pine forest, including tree and soil carbon, ranged from $99.5 \mathrm{Mg} \mathrm{ha}^{-1}$ to $65.6 \mathrm{Mg} \mathrm{ha}^{-1}$, declining with higher elevation on an elevational gradient from 1100 to 1500 masl. The leaves are three-needled, slender, 20 to $35 \mathrm{~cm}$ long. Long needles at the end of twigs may insulate terminal buds from fire as well as climate fluctuations. Although an evergreen species, a short leaf lifespan (423 days; Negi 2006) makes it briefly resemble a deciduous species during summer, as old needles are shed even before the new flush attain a quarter of their full length (Negi 2006). Although chir pine's population is centered on monsoonal areas, it is able to grow successfully even in dry hilly regions due to drought adaptations, with stomata that remain open until plant water potential declines to $-2.0 \mathrm{MPa}$ (Zobel et al. 2000; Singh et al. 2006). Nutrient use efficiency, especially of nitrogen $(\mathrm{N})$, is by far the highest, and foliage $\mathrm{N}$ concentration is the lowest, among the important tree species of the Himalaya (Singh and Singh 1992). Warm, dry 
southern and eastern aspects are preferred for regeneration (Majila and Kala 2010).

Chir pine has numerous fire-related adaptations, such as thick, fire-resistant bark that protects cambium from recurrent surface fires (Garkoti et al. 2001). Chir pine leaves on young trees can resprout from the stem and lower branches after grazing or fire injury. Ability to produce buds from close to the ground is regarded as a fire resilient characteristic, as it enables populations to survive and re-establish on burned sites (Garkoti et al. 2001). Accumulated needles limit competing plant growth and form an excellent surface fuel. Cones are resistant to high temperatures and viable seeds are released after cone heating, with open conditions and post-fire exposed mineral soil favored for seed germination (Ghildiyal et al. 2008).

Fire has played an important role in management of Himalayan forests and Indian forests in general. Human-ignited fires in Indian ecosystems have been linked to important cultural, religious, and practical objectives throughout history (Pyne 1994). Fire-stick burning dates back to the earliest people on the subcontinent; the grazing of livestock depended on regular burning to replenish forage, and burning was frequently applied to keep forests open and fuels low (Pyne 1994). The establishment of the Indian Forest Service in 1864 led to widespread campaigns to suppress fire and penalize burning (Pyne 1994). Setting fire was declared illegal under the 1927 Indian Forest Act and government fire protection was reiterated in the 1988 National Forest Policy (Reddy et al. 2017). Despite some degree of official acceptance of prescribed burning to control fuel loads, fire remains largely proscribed but nonetheless widespread, with official records largely under-reporting fire occurrence (Murthy et al. 2019). Fire frequency in chir pine stands has been estimated at 3 to $5 \mathrm{yr}$ in the Uttarakhand region, where it is difficult to find any stand that does not have evidence of recent fire (Semwal and Mehta 1996; Semwal et al. 2003; Brown et al. 2011). The fire regime is generally associated with the accumulation of large amounts $\left(\sim 6.5 \mathrm{Mg} \mathrm{ha}^{-1} \mathrm{yr}^{-1}\right)$ of flammable chir pine needles and twigs on the forest floor. Dry conditions in spring and summer months between April and June facilitate frequent fires (Kumar et al. 2015; Murthy et al. 2019). Of late, fire incidences have also been occasionally observed during autumn and winter seasons due to drier postmonsoon weather (Singh et al. 2016). While official records and unofficial observations are helpful, sitespecific quantitative information on fire occurrence is needed for better understanding of fire drivers, links to climate and land use, and short- and long-term effects.
Fire regimes-referring to the frequency, severity, type, spatial pattern, seasonality, and other characteristics of patterns of multiple fires in an ecosystem over many years-can be assessed in many ways, including through species traits, sedimentary deposits, historical records, and remote sensing (Jiang et al. 2020; Sannigrahi et al. 2020). One widely applied approach in the case of nonlethal surface fire is through tree-ring dating of scars left by fire in the cambium of surviving trees (Falk et al. 2011). Although dendrochronology is widely applied in India (e.g., Borgaonkar et al. 1994; Buckley et al. 2005; Yadav et al. 2009; Yadav 2011), quantitative field studies of fire occurrence using dendrochronological methods have been limited. In the only previously published work using fire-scarred trees in the Himalaya, Brown et al. (2011) carried out a pilot study during a dendroecological field week training exercise on samples from three chir pine trees near Srinagar, about $120 \mathrm{~km}$ northwest of the present study location. They reported a number of fires, including eight registered by at least two trees between 1974 and 2009 (Brown et al. 2011). They published their findings to demonstrate the utility of the technique and encourage future research (Brown et al. 2011).

We initiated the present study to develop a more extensive fire record at several sites in order to begin a fire network (Falk et al. 2011) that can be expanded in the future. Our objectives were to (1) apply consistent methods at multiple sites to establish comparable fire records in a forested region of high human use, typical of the lesser Himalaya; (2) interpret fire regime characteristics such as frequency and seasonality of fires in the context of ecologically and socially important impacts of fire; and (3) compare fire synchrony across our sites as well as to the relatively distant Srinagar site (Brown et al. 2011) to seek evidence of climatic and other drivers of regional fire occurrence.

\section{Methods \\ Study area}

The northern Indian states located in the Himalaya proper make up approximately $13 \%$ of the country. The present study was carried out in Uttarakhand, where anthropogenic forest fires are viewed as one of the major environmental and socio-economic issues (Negi 2019). The total geographical area of the state is $53483 \mathrm{~km}^{2}$, with forest cover estimated as $24303 \mathrm{~km}^{2}$, constituting $45.4 \%$ of the land (Forest Survey of India 2019). Official forest classification (Champion and Seth 1968) identifies chir pine, moist Siwalik sal (Shorea robusta Roth), ban oak (Quercus leucotrichophora A. Camus), and mixed broadleaf-conifer as the major forest types found in the state (Forest Survey of India 2019). Broadly, the forest types follow a horizontal distribution pattern along the elevational gradient from sal (300 to 1000 masl) in the 
south, chir pine (900 to 1800 masl) and ban oak (1500 to 2300 masl) in the middle, and evergreen coniferbroadleaved forests at higher altitudes ( $>2000$ masl) in the north. The fire-prone chir pine covers approximately $28 \%$ of the total forest cover, coinciding with the most densely populated elevational zone in the mountainous part of Uttarakhand.

\section{Field methods}

We selected three sites (BAD, PAN, SUN), each about 5 ha in size, located in forested patches between communities northeast of Almora (Fig. 1). Site names and codes are given in Table 1. Average precipitation in the mid-hills of Uttarakhand was $1002 \mathrm{~mm}$ (period of record 1964 to 2014) with peak rainfall in June through September, with dry winters (Panday et al. 2016). Average temperature was $9.2{ }^{\circ} \mathrm{C}$ in January and $25.1^{\circ} \mathrm{C}$ in July (period of record: 1991 to 2013; Panday et al. 2016). The sites were located on southeasterly or southwesterly aspects with mean slopes ranging from 26 to $55 \%$ (Table 1). The sites were relatively homogenous with no notable barriers to fire spread or shifts in topography within each site. With local foresters, we surveyed each site for fire-scarred trees. Scarring was common due to resin-tapping of trees as well as abundant charring from fires. These two mechanisms of wounding often interacted, with an initial resin-tapping scar penetrating the thick, protective bark, followed by numerous fire scars accumulating over time at the edge of the injury where the bark was thin. We targeted trees that appeared to have the longest period of scar recording and the greatest number of visible scars, an efficient and accurate approach to fire history reconstruction (Farris et al. 2013). A small partial cross-section was cut with a chain saw from one side of the fire-scarred wound on each sample tree, a method that minimizes damage to the trees (Heyerdahl and McKay 2017). A total of 36 samples was collected, 12 from each site (Table 1). In addition, 36 other trees were sampled with an increment borer to develop a local tree-ring chronology. Two cores were collected from each tree at breast height $(1.3 \mathrm{~m})$.

\section{Laboratory methods}

In the laboratory, we cut cross-section samples flat with a table saw and sanded them with progressively finer grits

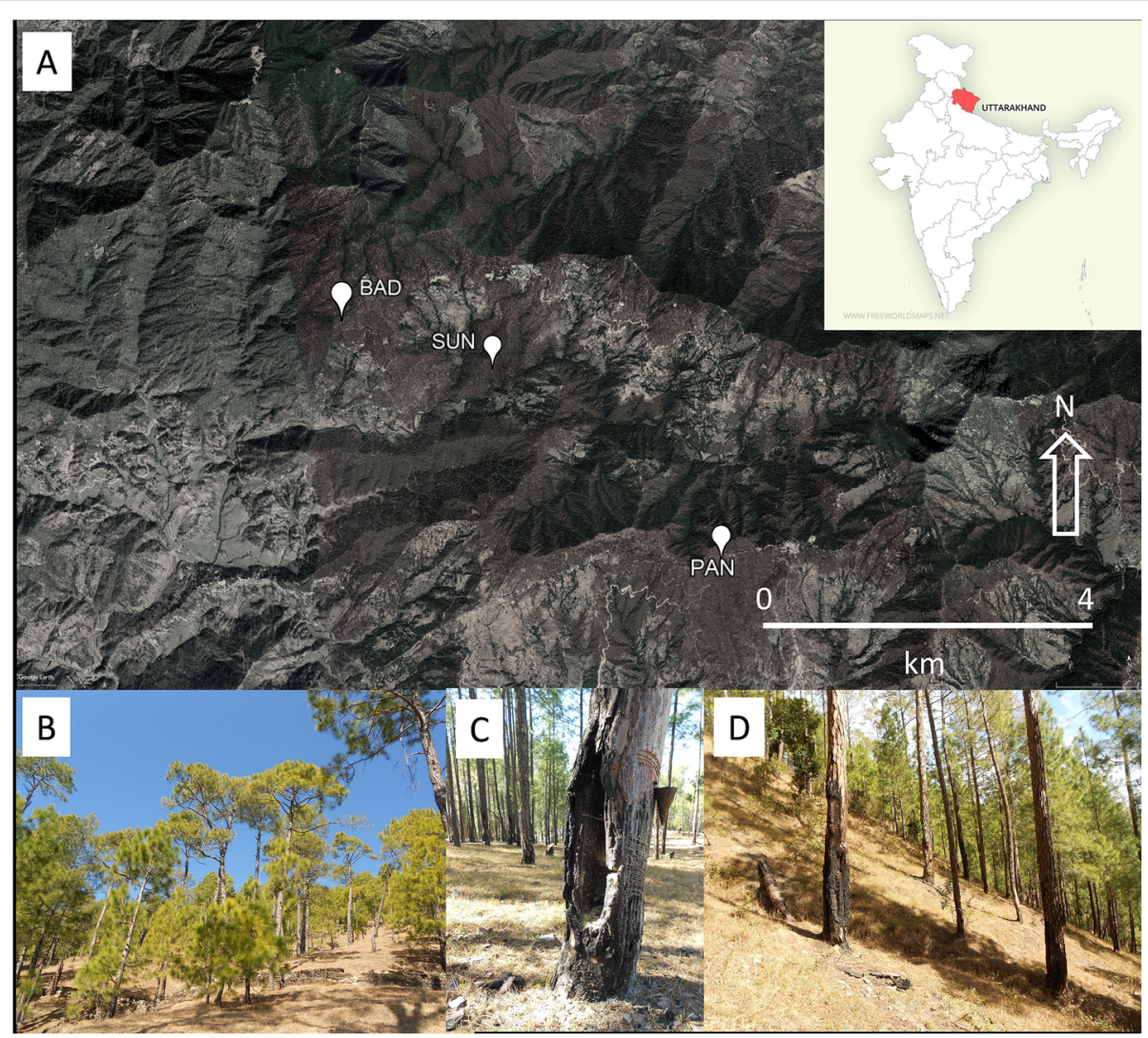

Fig. 1 (A) Map of study sites northeast of Almora, Uttarakhand, India, with Pinus roxburghii forests, 2017. Study site map was made in Google Earth and inset map is from http://www.freeworldmaps.net/asia/india/uttarakhand/where-is-uttarakhand.jpg. Photographs are from sites (B) PAN, (C) BAD, and (D) SUN. The tree in photo (C) illustrates scarring from resin collection and fire. Photographer credit, all photos: P.Z. Fulé, December 2017 
Table 1 Fire regime study site characteristics in Pinus roxburghii forest of Uttarakhand, India, 2017. Study site codes are referred to in the text and other tables and figures

\begin{tabular}{lllllll}
\hline Study site name & Code & Latitude & Longitude & Elevation $(\mathbf{m})$ & Slope $(\%)$ & Aspect \\
\hline Badaur Bend & BAD & 29.6689181 & 79.7595240 & 1777 & 25.7 & 38.6 \\
Panwanaula & PAN & 29.6413350 & 79.8030836 & 1848 & SW \\
Sundarvan & SUN & 29.6626349 & 79.7777136 & 1535 & 55.1 & SE \\
\hline
\end{tabular}

of sandpaper until the cells were clearly visible under magnification. Increment cores were glued to wooden mounts and sanded. We visually cross-dated the tree-rings and measured them with a sliding stage (Velmex, Inc., Bloomfield, New York, USA) or scanned and measured them with image analysis software (Coo Recorder program; CybisElektronik \& Data AB, Saltsjöbaden, Sweden). We checked cross-dating quality with COFECHA software (Holmes 1983) and errors were corrected. We identified fire-scar dates and intra-annual position of the wounds following the designations of Baisan and Swetnam (1990): dormant season, early-, mid-, or late-earlywood, and latewood. Dormant-season scars could have occurred anytime outside the summer growing season but, based on the overwhelming prevalence of spring to earlysummer fires reported in the Himalaya (Kumar et al. 2015; Murthy et al. 2019), we assumed that dormantseason scars primarily formed in the spring.

We assembled fire-scar data into FHX2-format files and analyzed fire-interval distributions, seasonality, and fire-climate links with Fire History Analysis and Exploration System (FHAES) software (Sutherland et al. 2017). We measured the similarity of fire occurrence between sites and from site-region (all sites combined) using the Jaccard Index, which ranges from 0 (complete dissimilarity) to 1 (complete similarity) (Sutherland et al. 2017). We analyzed fire interval distributions with parametric statistics and also fit a Weibull function (Sutherland et al. 2017) to express fire interval statistics in probabilistic terms. All fire interval analyses were based on fire dates with at least two fire scars and two recording samples per site, as well as a regional analysis of all sites combined. We chose to use these criteria for the regional analysis rather than proportional filtering (e.g., a filter of fire dates in which $25 \%$ or more of the recording samples were scarred; Baisan and Swetnam 1990) because preliminary assessment of the low degree of firedate synchrony across sites indicated that few fire dates reached the $25 \%$ threshold when all sites were combined, resulting in an apparent decline in regional fire occurrence compared to individual site occurrence.

We assessed fire-climate relationships using superposed epoch analysis (SEA) in FHAES software (Sutherland et al. 2017). We created fire-event files listing all fire dates and those scarring $25 \%$ or more of recording trees within each site. Climate data came from precipitation records for the mid-elevations of Uttarakhand (Panday et al. 2016). Data were available for the period 1964 to 2014. We calculated annual precipitation based on water years, 1 October to 30 September. The SEA compared precipitation in fire years as well as a window of five preceding and two succeeding years, a time frame commonly used in such analyses to help identify switches from dry to wet periods such as those associated with El Niño-Southern Oscillation (Stephens et al. 2003). Statistical significance $(P=0.05)$ was estimated from 1000 bootstrapped values of precipitation.

\section{Results}

The $P$. roxburghii tree-rings cross-dated well, although there were numerous false rings. From the increment cores, we developed a chronology from 1900 to 2017 with a total of 36 series $(R=0.46)$. Eight of the 36 firescarred samples were from dead trees (stumps or snags), the remainder from living trees. Attributes of the sampled trees are shown in Table 2.

The oldest dated fire was in 1888 but then there was a long gap in the record until 1923 (Fig. 2). Fires were recorded regularly from the 1920s to the present, but the sample depth was relatively low until the 1950s and the presence of multiple trees scarred in the same year mainly occurred from the 1970s onward. Synchrony of fire dates across sites was low, despite a high number of recent fire years: there were 31 fire dates out of 43 years in the period 1975 to 2017. Only two fire years, 1995 and 1999, were synchronous across all three sites and represented by two or more of the recording trees within sites (Fig. 2). The lack of similarity among sites was indicated by the low values of the Jaccard Index (Table 3). All values between pairs of sites were below 0.20; the highest similarity from a site to the region (all sites combined) was 0.54 (Table 3). Within sites, there were numerous fire years in which $50 \%$ or more of the recording trees were scarred, representing fire events that burned across all or most of the site. However, each site also had isolated fire dates recorded by only one to two samples, likely representing fires that were relatively small within the roughly 5 ha study sites.

A few individual trees captured an extraordinarily high number of scars. One tree at the BAD site was scarred 11 times in 22 years, including a 3-year period of consecutive fires (2007 to 2009). This tree 
Table 2 Fire-scarred sample characteristics in Pinus roxburghii forest of Uttarakhand, India, 2017. Study site codes are shown in Table 1. $\mathrm{DBH}=$ diameter at breast height $(1.3 \mathrm{~m})$

\begin{tabular}{llllll}
\hline Study site code & Mean DBH $(\mathbf{c m})$ & DBH range $(\mathbf{c m})$ & Living tree samples $(\mathbf{n})$ & Dead tree samples $(\mathbf{n})$ & Total samples $(\mathbf{n})$ \\
\hline BAD & 43.8 & 32.0 to 65.0 & 8 & 4 & 12 \\
PAN & 40.8 & 19.0 to 58.5 & 11 & 1 & 12 \\
SUN & 43.0 & 22.0 to 60.0 & 9 & 3 & 12 \\
\hline
\end{tabular}

was located next to a convenient flat opening with evidence of camping and a staging area for forest resource extraction, perhaps explaining the high frequency of burning. The most frequently scarred tree at the PAN site, in contrast, had nine fires in the same 22 years but was just a small $(19 \mathrm{~cm}$ diameter at breast height $[1.3 \mathrm{~m}])$ tree in the midst of an average area of forest.

Fires recurred frequently (average $<6$ yr) at all sites, as shown by the different statistics in Table 4 . Mean fire intervals ranged from 4.2 to $5.3 \mathrm{yr}$. The minimum interval between fire years was $1 \mathrm{yr}$ at all sites and the longest maximum fire-free interval was $24 \mathrm{yr}$ at the SUN site. Median fire intervals were several years shorter than the means ( 2 to $3.5 \mathrm{yr}$ ), indicating that the fire interval distributions were skewed toward shorter intervals, but the long tails of the distributions reached out to 15 to 24 yr, depending on the site. Weibull functions fit the fire interval data and Weibull means were similar in magnitude to the parametric means (Table 4). The average point (or per-sample) mean fire intervals ranged from 6.1 to $8.3 \mathrm{yr}$ (Table 4), corresponding to 130 to $320 \%$ longer than the average composite mean fire interval.

Regional fire occurrence was estimated by aggregating all three sites (Table 4). In this context, a "regional fire date" refers to a fire event anywhere in the three sites, as long as it was represented by at least two fire-scarred

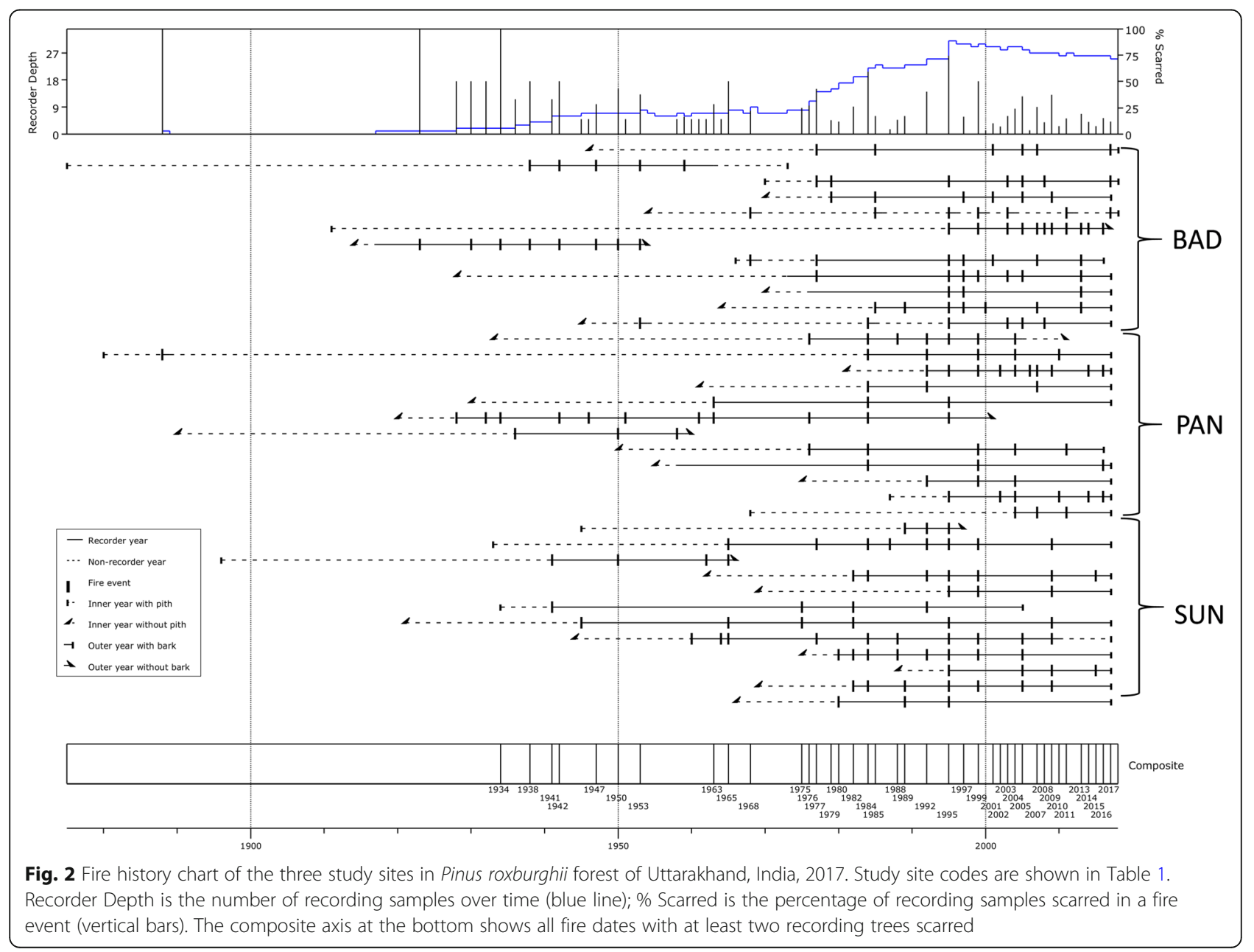


Table 3 Jaccard similarity of fire occurrence across the three study sites and by region (all three sites combined) in Pinus roxburghii forest of Uttarakhand, India, 2017. Study site codes are shown in Table 1. The Jaccard Index ranges from 0 (complete dissimilarity) to 1 (complete similarity). Empty cells at bottom left of the table are duplicates of the cells symmetrically located across the central diagonal

\begin{tabular}{lllll}
\hline Study site & BAD & PAN & SUN & Region \\
\hline BAD & 1.000 & 0.148 & 0.185 & 0.541 \\
PAN & & 1.000 & 0.167 & 0.342 \\
SUN & & & 1.000 & 0.417 \\
Region & & & & 1.000 \\
\hline
\end{tabular}

trees. Given the lack of synchrony between sites noted above, the regional record logically showed a much higher fire frequency, with a mean and Weibull mean both equaling $2.2 \mathrm{yr}$. The regional fire frequency was 0.46 fires $\mathrm{yr}^{-1}$, indicating a nearly $50 \%$ chance of fire in at least one of the three sites annually (Table 4).

Superposed epoch analysis showed almost no relationship between annual precipitation and fire events. Only at one site, PAN, was there a statistically significant link between dry conditions in fire years (data not shown). At site SUN, there were statistically significant wet conditions two years before fire events (data not shown).

Table 4 Fire return interval analyses by study site and by region (all three sites combined) in Pinus roxburghii forest of Uttarakhand, India, 2017. Study site codes are shown in Table 1. All composite analyses are based on a minimum of two samples and two fire scars

\begin{tabular}{lllll}
\hline Parameters & BAD & PAN & SUN & Region \\
\hline Composite & & & & \\
Total number of intervals & 19 & 12 & 14 & 38 \\
Mean fire interval (yr) & 4.16 & 4.42 & 5.29 & 2.18 \\
Median fire interval (yr) & 2 & 3 & 3.5 & 2 \\
Standard deviation (yr) & 3.69 & 3.48 & 5.85 & 1.84 \\
Frequency (fires yr $^{-1}$ ) & 0.24 & 0.23 & 0.19 & 0.46 \\
Coefficient of variation & 0.89 & 0.79 & 1.11 & 0.84 \\
Skewness & 1.79 & 1.67 & 2.88 & 2.69 \\
Kurtosis & 3.13 & 2.42 & 9.11 & 8.81 \\
Minimum fire interval (yr) & 1 & 1 & 1 & 1 \\
Maximum fire interval (yr) & 15 & 13 & 24 & 10 \\
Weibull mean (yr) & 4.2 & 4.46 & 5.34 & 2.21 \\
Weibull median (yr) & 3.43 & 3.84 & 4.12 & 1.88 \\
Individual-sample & & & & \\
Point mean fire interval (yr) & 6.07 & 8.33 & 6.76 & 6.95 \\
\hline
\end{tabular}

\section{Discussion}

By applying consistent methods across three 5 ha study sites in the Almora region, this study permits comparison of fire regimes in multiple $P$. roxburghii forests and may serve as a nucleus for a future research network of fire study sites. The increasing effects of fire on ecosystem services under warming climate and population pressures in South Asia is a threat to the sustainability of socio-ecological systems (SES). Quantitative assessment of fire occurrence, as in this study, is one piece of a larger enterprise integrating natural and social sciences to address climate adaptation and SES persistence. Limitations to the study included constraints on budget and time for field sampling, resulting in a limited data set based on accessible sites. Future research should include a broader geographic representation with deeper data sets enhanced with additional ecological measurements such as forest structure, age distribution, and fuel accumulation. Social science investigation of the cultural and economic factors affecting forest use and fire management, as well traditional fire use by indigenous peoples, is also needed.

Surface fires recurred frequently at all three study sites, all with mean fire intervals $<6 \mathrm{yr}$ and burning continuing up to the present. Mean fire intervals were similar to those found in other fire-adapted pine forests of the northern hemisphere such as Pinus ponderosa C. Lawson, $P$. nigra R. Legay, $P$. hartwegii Lindl., $P$. jeffreyi Balf., and P. strobiformis Engelm. (Stephens et al. 2003; Christopoulou et al. 2013; Yocom Kent et al. 2017). In many parts of the world, however, frequent surface fire regimes were interrupted in the nineteenth and twentieth centuries (Falk et al. 2011). Ongoing frequent fire regimes are rare in pine forests of North America or Europe, except under unusual circumstance such as remote sites or management by indigenous peoples (Fulé et al. 2011). Much of the world remains unstudied in terms of detailed fire regime over multidecadal to multicentury scales; evidence from recent decades of satellite imagery indicates that many tropical and subtropical forests do experience fire frequently (Andela et al. 2019).

The fire-scar records at our sites were relatively brief, with most trees entering the record around the 1960s (Fig. 2). The brevity is likely a combination of many trees being relatively young as well as our sampling protocol that sought to remove only small partial cross-sections to minimize damage to the trees. We found little evidence of older wood, such as stumps or downed logs, that could have carried the fire-scar record further into the past. The absence of old wood might be due to removal of wood for domestic use as well as consumption by frequent fires.

The seasonality of fire scarring had two modes-in the dormant and middle-earlywood periods of ring growth 
(Fig. 3)-matching our assumption that dormant-season scarring likely occurred before cambial growth in the spring rather than after growth cessation in the fall. Fewer than $2 \%$ of fire scars were observed in latewood, consistent with the limited pre-monsoon fire pattern observed by foresters in the region.

Interaction of wounding mechanisms appeared to play an important role, with resin-tapped trees having an entry court through the thick bark of $P$. roxburghii for subsequent wounding by repeated fires. This interaction has many implications for the present study. First, it is possible that some initial wounds or first scars on samples are due to the resin tap, rather than a fire. The selection of a 2-scar minimum for inclusion of a fire year in the composite fire interval analysis eliminated years represented by a single scar event from affecting the fire regime analysis. Furthermore, there was virtually no synchrony of first-scar dates within sites (Fig. 2). A second implication is that the temporal pattern of fires detected in the study may be related to patterns of resin tapping, driven by market forces or legislation. Fires were mainly detected after 1970 and frequency increased again after 2000. Resin is an important economic product globally (Cunningham 2012) and India is in the top 20 producing nations (Van der Maaten et al. 2017). Past research has looked at resin tapping from the perspective of economic efficiency (Lohani 1985) but there is little literature on the environmental impacts of resin tapping or the legislative, cultural, and economic context of the practice in Uttarakhand. It would be useful to know if fire incidence is actually increasing in recent years or perhaps if increasing resin tapping is allowing for better recording of fires. A third implication of the interaction of resin tapping and fire is accelerated tree mortality.
We observed numerous dead trees with substantial wounding from resin tapping (example illustrated in Fig. 1) in the region, although we could not systematically measure the occurrence of tapping due to subsequent burning and enlargement of the original wound. In some cases, reburning of wounded trees led to them being burned through at the base and toppled by winds, a phenomenon we also noted in resin-tapped and burned Pinus merkusii Jungh. \& de Vriese trees in Indonesia (Hartiningtias et al. 2020).

Synchrony of fire occurrence is a key fingerprint of the drivers of fire regimes. Climate is a top-down driver affecting broad regions simultaneously (Hudson et al. 2019), typically leading to high landscape- or regionallevel synchrony of burning during periodic droughts (Yocom Kent et al. 2017; Arizpe et al. 2020). In contrast, human-caused ignitions are bottom-up drivers that often vary from place to place (Flatley et al. 2015), reducing broad-scale fire synchrony. People likely select lesssevere conditions to light fires, further decoupling the fire regime from climate. Identifying climatically distinct (Fulé et al. 2008) or geographically distinct (Kaye and Swetnam 1999) patterns of asynchrony has been considered as evidence of human-caused ignitions, although it is important to note that topography and breaks in fuel continuity also affect synchrony (Iniguez et al. 2008; Ireland et al. 2012).

The lack of synchrony and the lack of significant association of fire with dry years in two of the three sites among the three study sites at Almora suggests a bottom-up, human-driven fire regime. The sites burned very frequently with a fire in at least one site occurring every two years, but synchrony was strikingly low: only two fire years (1995 and 1999) were synchronous across

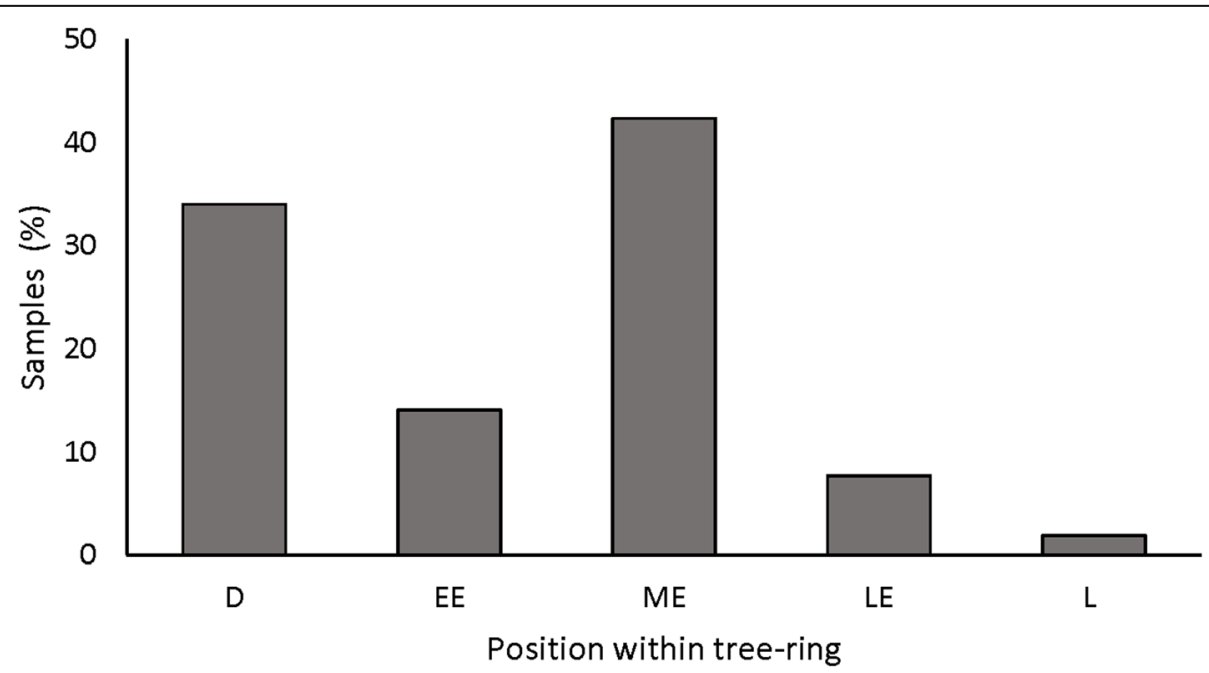

Fig. 3 Seasonal distribution of fire events as inferred from position of the fire-caused injury within the growing ring in Pinus roxburghii forest of Uttarakhand, India, 2017. Positions are dormant (D), early-earlywood (EE), middle-earlywood (ME), late-earlywood (LE), and latewood (L) 
all three sites, scarring two or more samples, and fire regimes between pairs of sites were also highly dissimilar (Table 3). Reaching further afield to the only other dendrochronological fire regime study of $P$. roxburghii, the data set compiled at Srinagar by Brown et al. (2011) was based on only three trees, so a comparison of dates is of limited utility, but five of the eight years in which two or more of their trees recorded fires were also fire years at one or more of our sites. Some evidence for climatic synchronization comes from 1995, one of the synchronous years between the Srinagar site (Brown et al. 2011) and the Almora region of our study. The 1995 fire event was the most pronounced fire year at our sites, in which $77 \%$ of the recording samples was scarred, as well as a major fire year in the Himalayan region (Sharma and Pant 2017).

Fire plays an increasing role in global ecosystems as climate warming lengthens fire seasons (Jolly et al. 2015) and growing populations rely even more heavily on natural resources. Interactions of climate and fire with other disturbances such as insect herbivory are likely to further alter forests in uncertain ways (Waring et al. 2009). Human-caused fires and resin tapping will continue in the lesser Himalaya of Uttarakhand as climate warms in this century, but management that incorporates fire regime information and the social drivers for fire use could help sustain ecosystem services from pine forests. Fire, like other ecological disturbances, has effects that can be viewed as positive or negative from different ecological and social perspectives. Burning in the Himalayan foothills is largely motivated by the desire to stimulate forage production for livestock. Additional positive elements include maintaining low levels of surface fuels and controlling tree regeneration, thereby limiting ladder and canopy fuels. A regime of prescribed surface fire is a well-understood method for limiting the severity of subsequent wildfires in pine forests (Shive et al. 2013). Viewing the same set of facts from a different lens can foster a negative perspective, however: by reducing dead and living biomass, repeated fires constrain the carbon storage capacity of the forest (Singh et al. 2019). The fact that there is no officially sanctioned mechanism for most burning sets up an unfortunate barrier to communication and cooperation between local communities, foresters, and researchers. Examples from other nations, such as Mexico, show that official opposition to fire can be reconciled with traditional fire use (Rodríguez-Trejo et al. 2011). In the Indian context, Sharma and Pant (2017) recommend co-producing fire science with resource managers and community stakeholders.

\section{Conclusions}

Quantitative fire regime data was reconstructed from fire-scarred chir pines in an incipient network. Fires recurred with high frequency but low severity, relatively decoupled from climatic fluctuation and with low synchrony across the landscape, consistent with a humanignited frequent-fire regime. Ultimately, broader interdisciplinary research into fire and its environmental and social context is essential to develop well-grounded strategies for climate adaptation and protection of ecosystem services. The interaction of anthropogenic fire with the widespread practice of resin tapping also merits further investigation at landscape to regional scales with attention to developing practical, sustainable restoration strategies. Linking science and management across temporal and spatial scales in a structured manner, as recommended by Joseph et al. (2009), has potential for helping managers improve resource conservation in India. We suggest developing a research network of dendroecological study sites in Himalayan coniferous forests, extending into pine forests across southeast Asia into Indonesia, to assess interacting disturbances and their ecological and social implications.

\section{Acknowledgements \\ Thanks to the Department of Forest, Government of Uttarakhand. \\ Authors' contributions \\ PF, SG, and RS designed the study and carried out data collection. PF carried out dendrochronology and statistical analysis. PF, SG, and RS all contributed to writing and editing the text. All authors read and approved the final manuscript.}

\section{Funding}

GIAN grant \#174027C02 to P.Z. Fulé for travel to India.

Availability of data and materials

Data are archived at the International Multiproxy Paleofire

Database (IMPD; https://www.ncdc.noaa.gov/data-access/paleoclimatologydata/datasets/fire-history).

\section{Declarations}

Ethics approval and consent to participate Not applicable.

\section{Consent for publication}

Not applicable.

\section{Competing interests}

The authors declare that they have no competing interests.

\section{Author details}

${ }^{1}$ School of Forestry, Northern Arizona University, P.O. Box 15018, Flagstaff, Arizona 86011, USA. ${ }^{2}$ School of Environmental Sciences, Jawaharlal Nehru University, New Mehrauli Road, New Delhi 110067, India. ${ }^{3}$ Independent Scholar, New Dehli, India.

Received: 22 February 2021 Accepted: 13 May 2021

Published online: 24 June 2021

\footnotetext{
References

Andela, N., D.C.L. Morton, R. Giglio, Y. Paugam, Y. Chen, S. Hantson, G.R. van der Werf, and J.T. Randerson. 2019. The Global Fire Atlas of individual fire size, duration, speed and direction. Earth System Science Data 11: 529-552. https:// doi.org/10.5194/essd-11-529-2019.

Arizpe, A.H., D.A. Falk, C.A. Woodhouse, and T.W. Swetnam. 2020. Widespread fire years in the US-Mexico Sky Islands are contingent on both winter and
} 
monsoon precipitation. International Journal of Wildland Fire 29 (12): $1072-$ 1087. https://doi.org/10.1071/WF19181.

Baisan, C.H., and T.W. Swetnam. 1990. Fire history on a desert mountain range: Rincon Mountain Wilderness, Arizona, USA. Canadian Journal of Forest Research 20: 1559-1569. https://doi.org/10.1139/x90-208.

Borgaonkar, H.P., G.B. Pant, and K.R. Kumar. 1994. Dendroclimatic reconstruction of summer precipitation at Srinagar, Kashmir, India, since the late-eighteenth century. The Holocene 4: 299-306. https://doi.org/10.1177/0959683694004003 09.

Brown, P.M., A. Bhattacharyya, and S.K. Shah. 2011. Potential for developing fire histories in chir pine (Pinus roxburghii) in the Himalayan foothills. Tree-Ring Research 67 (1): 57-62. https://doi.org/10.3959/2009-15.1.

Buckley, B.M., B.I. Cook, A. Bhattacharya, D. Dupka, and V. Chaudry. 2005. Global surface temperature signals in pine ring-width chronologies from southern monsoon Asia. Geophysical Research Letters 32: L20704. https://doi.org/10.102 9/2005GL023745.

Champion, H.G., and S.K. Seth. 1968. A revised survey of the forest types of India. New Delhi: Government of India Publications.

Christopoulou, A., P.Z. Fulé, P. Andriopoulos, D. Sarris, and M. Arianoutsou. 2013. Dendrochronology-based fire history of Pinus nigra forests in Mount Taygetos, Southern Greece. Forest Ecology and Management 293: 132-139. https://doi.org/10.1016/j.foreco.2012.12.048.

Cunningham, A. 2012. Pine resin tapping techniques used around the world. In Pine Resin: Biology, Chemistry and Applications, ed. A.G. Fett-Neto, 1-8 ISBN: 978-81-308-0493-4

Ellison, A.M. 2019. Foundation species, non-trophic interactions, and the value of being common. iscience 13: 254-268. https://doi.org/10.1016/j. isci.2019.02.020.

Falk, D.A., E.K. Heyerdahl, P.M. Brown, C. Farris, P.Z. Fulé, D. McKenzie, T.W. Swetnam, A.H. Taylor, and M.L. Van Horne. 2011. Multiscale controls of historical forest fire regimes: New insights from fire-scar networks. Frontiers in Ecology and the Environment 9 (8): 446-454. https://doi.org/10.1890/100052.

Farris, C., C. Baisan, D. Falk, M. Van Horne, P. Fulé, and T. Swetnam. 2013. A comparison of targeted and systematic fire-scar sampling for estimating historical fire frequency in Southwestern ponderosa pine forests. International Journal of Wildland Fire 22 (8): 1021-1033. https://doi.org/10.1071/WF13026.

Flatley, W.T., C.W. Lafon, H.D. Grissino-Mayer, and L.B. LaForest. 2015. Changing fire regimes and old-growth forest succession along a topographic gradient in the Great Smoky Mountains. Forest Ecology and Management 350: 96-106. https://doi.org/10.1016/j.foreco.2015.04.024.

Forest Survey of India. 2019. Ministry of Environment Forest and Climate Change, Dehradun, Uttarakhand, India. https://fsi.nic.in/forest-report-2019?pglD=forestreport-2019. Accessed 17 Feb 2021.

Fulé, P.Z., M. Ramos-Gómez, C. Cortés-Montaño, and A.M. Miller. 2011. Fire regime in a Mexican forest under indigenous resource management. Ecological Applications 21 (3): 764-775. https://doi.org/10.1890/10-0523.1.

Fulé, P.Z., M. Ribas, E. Gutiérrez, R. Vallejo, and M.W. Kaye. 2008. Forest structure and fire history in an old Pinus nigra forest, eastern Spain. Forest Ecology and Management 255: 1234-1242. https://doi.org/10.1016/j.foreco.2007.10.046.

Garkoti, S.C., D.B. Zobel, and S.P. Singh. 2001. Leaf conductance of primary and mature leaves of Pinus roxburghii: A comparison. Journal of Forest Research 6: 1-5. https://doi.org/10.1007/BF02762715.

Ghildiyal, S.K., C.M. Sharma, and S. Gairola. 2008. Effect of temperature on cone bursting, seed extraction and germination in five provenances of Pinus roxburghii from Garhwal Himalaya in India. Southern Forests: a Journal of Forest Science 70 (1): 1-5. https://doi.org/10.2989/SOUTH.FOR.2008.70.1.1.511.

Hartiningtias, D., P.Z. Fulé, and A. Gunawan. 2020. Wildfire effects on forest structure of Pinus merkusii in Sumatra, Indonesia. Forest Ecology and Management 457: 117660. https://doi.org/10.1016/j.foreco.2019.117660.

Heyerdahl, E.K., and S.J. McKay. 2017. Condition of live fire-scarred ponderosa pine twenty-one years after removing partial cross-sections. Tree-Ring Research 73: 149-153. https://doi.org/10.3959/1536-1098-73.2.149.

Holmes, R.L. 1983. Computer-assisted quality control in tree-ring dating and measurements. Tree-Ring Bulletin 43: 69-78.

Hudson, A.R., R. Alfaro-Sanchez, F. Babst, S. Belmecheri, D.J.P. Moore, and V. Trouet. 2019. Seasonal and synoptic climatic drivers of tree growth in the Bighorn Mountains, WY, USA (1654-1983 CE). Dendrochronologia 58: 125633. https://doi.org/10.1016/j.dendro.2019.125633.

Iniguez, J.M., T.W. Swetnam, and S.R. Yool. 2008. Topography affected landscape fire history patterns in southern Arizona, USA. Forest Ecology and Management 256: 295-303. https://doi.org/10.1016/j.foreco.2008.04.023.
Ireland, K.B., A.B. Stan, and P.Z. Fulé. 2012. Bottom-up control of a northern Arizona ponderosa pine forest fire regime in a fragmented landscape. Landscape Ecology 27 (7): 983-997. https://doi.org/10.1007/s10980-0129753-0.

Jiang, Y., L. Zhou, and A. Raghavendra. 2020. Observed changes in fire patterns and possible drivers over Central Africa. Environmental Research Letters 15: 0940b8. https://doi.org/10.1088/1748-9326/ab9db2.

Jolly, W.M., M.A. Cochrane, P.H. Freeborn, Z.A. Holden, T.J. Brown, G.J. Williamson, and D.M.J.S. Bowman. 2015. Climate-induced variations in global wildfire danger from 1979 to 2013. Nature Communications 6: 7537. https://doi.org/1 0.1038/ncomms8537.

Joseph, S., K. Anitha, and S.R. Murthy. 2009. Forest fire in India: a review of the knowledge base. Journal of Forest Research 14 (1): 27-134. https://doi.org/1 0.1007/s10310-009-0116-x.

Kaye, M.W., and T.W. Swetnam. 1999. An assessment of fire, climate, and Apache history in the Sacramento Mountains, New Mexico. Physical Geography 20: 305-330. https://doi.org/10.1080/02723646.1999.10642681.

Kumar, S., M. Kumar, and M.A. Sheik. 2013. Carbon stock variation of Pinus roxburghii Sarg. forest along altitudes of Garhwal Himalaya, India. Russian Journal of Ecology 44 (2): 131-136. https://doi.org/10.1134/\$106741361302 0136.

Kumar, S., G.D. Bairagi Meenakshi, and A. Kumar. 2015. Identifying triggers for forest fire and assessing fire susceptibility of forests in Indian western Himalaya using geospatial techniques. Natural Hazards 78: 203-217. https:// doi.org/10.1007/s11069-015-1710-1.

Lohani, D.N. 1985. Resin tapping in chir pine. U.P. Forest Bulletin No. 51. Lucknow, India: R \& D Circle, Uttar Pradesh.

Majila, B.S., and C.P. Kala. 2010. Forest structure and regeneration along the altitudinal gradient in the Binsar Wildlife Sanctuary, Uttarakhand Himalaya, India. Russian Journal of Ecology 41 (1): 75-83. https://doi.org/10.1134/S1 067413610010157.

Murthy, K.K., S.K. Sinhab, R. Kaulb, and S. Vaidyanathanc. 2019. A fine-scale statespace model to understand drivers of forest fires in the Himalayan foothills. Forest Ecology and Management 432: 902-911. https://doi.org/10.1016/j. foreco.2018.10.009

Negi, G.C.S. 2006. Leaf and bud demography and shoot growth in evergreen and deciduous trees of central Himalaya, India. Trees 20: 416-429. https://doi. org/10.1007/s00468-006-0056-4.

Negi, G.C.S. 2019. Forest fire in Uttarakhand: causes, consequences and remedial measures. International Journal of Ecology and Environmental Sciences 45 (1): $31-37$.

Negi, G.C.S., and R.L. Semwal. 2010. Valuing the services provided by forests and agro-ecosystems in the Central Himalaya. Mountain Forum Bulletin 10(1): 4447.

Panday, S.C., A.K. Srivastva, N.S. Murty, J.K. Bisht, J.C. Bhatt, H.S. Gupta, and A. Pattanayak. 2016. Climate and crop planning for mid-hills of Uttarakhand. Almora: ICAR-VPKAS, India.

Pyne, S.J. 1994. Nataraja: India's cycle of fire. Environmental History Review 18 (3): 1-20. https://doi.org/10.2307/3984707.

Reddy, C.S., C.S. Jha, G. Manaswini, V.V.L. Padma Alekhya, S. Vazeed Pasha, K.V. Satish, P.G. Dikawar, and V.K. Dadhwal. 2017. Nationwide assessment of forest burnt area in India using Resourcesat-2 AWiFS data. Current Science 112 (7): 1521-1532. https://doi.org/10.18520/cs/v112/i07/1521-1532.

Rodríguez-Trejo, D.A., P.A. Martínez-Hernández, H. Ortiz-Contla, M.R. ChavarríaSánchez, and F. Hernández-Santiago. 2011. The present status of fire ecology, traditional use of fire, and fire management in Mexico and Central America. Fire Ecology 7 (1): 40-56. https://doi.org/10.4996/fireecology.0701040.

Sannigrahi, S., F. Pilla, B. Basu, A.S. Basu, K. Sarkar, S. Chakraborti, P.K. Joshi, Q. Zhang, Y. Wang, S. Bhatt, A. Bhatt, S. Jha, S. Keesstra, and P.S. Roy. 2020 Examining the effects of forest fire on terrestrial carbon emission and ecosystem production in India using remote sensing approaches. Science of the Total Environment 725: 138331. https:/doi.org/10.1016/j.scitotenv.2020.138331.

Semwal, R.L., S. Chatterjee, J.C. Punetha, S. Pradhan, P. Dutta, S. Soni, G. Sharma, V. P. Singh, and A. Malayia. 2003. Forest fires in India: lessons from case studies. WWF India.

Semwal, R.L., and J.P. Mehta. 1996. Ecology of forest fires in chir pine (Pinus roxburghii Sarg.) forests of Garhwal Himalaya. Current Science 70: 426-427.

Sharma, S., and H. Pant. 2017. Vulnerability of Indian Central Himalayan forests to fire in a warming climate and a participatory preparedness approach based on modern tools. Current Science 112 (10): 2100-2105. https://doi.org/10.1852 o/cs/v112/i10/2100-2105. 
Shive, K.L., C.H. Sieg, and P.Z. Fulé. 2013. Pre-wildfire management treatments interact with fire severity to have lasting effects on post-wildfire vegetation response. Forest Ecology and Management 297: 75-83. https://doi.org/10.101 6/j.foreco.2013.02.021.

Singh, J.S., and S.P. Singh. 1992. Forests of the Himalaya, structure functioning and impact of man. Nainital: Gyanodaya Prakashan.

Singh, R.D., S. Gumber, P. Tewari, and S.P. Singh. 2016. Nature of forest fires in Uttarakhand: frequency, size and seasonal patterns in relation to premonsoonal environment. Current Science 111 (2): 398-403. https://doi.org/1 0.18520/cs/v111/i2/398-403.

Singh, S.P., A. Pandey, and V. Singh. 2019. Nature and extent of forest degradation in central Himalayas. Chapter 3. In Tropical Ecosystems: Structure, Functions, and Challenges in the Face of Global Change, ed. S.C. Garkoti, S.J. Van Bloem, P.Z. Fulé, and R.L. Semwal, 27-43. Singapore: Springer Nature. https://doi.org/10.1007/978-981-13-8249-9_3.

Singh, S.P., D.B. Zobel, S.C. Garkoti, A. Tewari, and C.M.S. Negi. 2006. Patterns in water relations of central Himalayan trees. Tropical Ecology 47: 159-182.

Stephens, S.L., C.N. Skinner, and S.J. Gill. 2003. Dendrochronology-based fire history of Jeffrey pine - mixed conifer forests in the Sierra San Pedro Martir, Mexico. Canadian Journal of Forest Research 33: 1090-1101. https://doi.org/1 0.1139/X03-031.

Sutherland E.K., P.W. Brewer, D.A. Falk, and M.E. Velásquez. 2017. Fire history analysis and exploration system (FHAES) user manual. Laboratory of TreeRing Research, University of Arizona. Available at http://www.fhaes.org.

Troup, R.S. 1921. The silviculture of Indian trees. Vol. I-III. Oxford: Clarendon Press.

Van der Maaten, E., A. Mehl, M. Wilmking, and M. van der Maaten-Theunissen. 2017. Tapping the tree-ring archive for studying effects of resin extraction on the growth and climate sensitivity of Scots pine. Forest Ecosystems 4 (1): 7. https://doi.org/10.1186/s40663-017-0096-9.

Waring, K.M., D.M. Reboletti, L.A. Mork, M. Li, C.-H. Huang, R.W. Hofstetter, A.M. Garcia, P.Z. Fulé, and T.S. Davis. 2009. Modeling the impacts of two bark beetle species under warming climate in the southwestern U.S.A.: ecological and economic consequences. Environmental Management 44: 824-835. https://doi.org/10.1007/s00267-009-9342-4.

Yadav, R.R. 2011. Tree-ring evidence of 20th century precipitation surge in monsoon shadow zone of western Himalaya, India. Journal of Geophysical Research 116: D2. https://doi.org/10.1029/2010JD014647.

Yadav, R.R., A. Braeuning, and J. Singh. 2009. Tree ring inferred summer temperature variations over the last millennium in western Himalaya, India. Climate Dynamics 36: 1545-1554. https://doi.org/10.1007/s00382 009-0719-0.4.

Yocom Kent, L.L., P.Z. Fulé, P.M. Brown, J. Cerano-Paredes, E. Cornejo-Oviedo, C. Cortés Montaño, S.A. Drury, D.A. Falk, J. Meunier, H.M. Poulos, C.N. Skinner, S. L. Stephens, and J. Villanueva-Díaz. 2017. Climate drives fire synchrony but local factors control fire regime change in northern Mexico. Ecosphere 8 (3): e01709. https://doi.org/10.1002/ecs2.1709.

Zobel, D.B., S.C. Garkoti, S.P. Singh, A. Tewari, and C.M.S. Negi. 2000. Patterns of water potentials among forest types of the central Himalaya. Current Science 80: 774-779 https://www.jstor.org/stable/24105664.

\section{Publisher's Note}

Springer Nature remains neutral with regard to jurisdictional claims in published maps and institutional affiliations.

\section{Submit your manuscript to a SpringerOpen ${ }^{\circ}$ journal and benefit from:}

- Convenient online submission

- Rigorous peer review

- Open access: articles freely available online

- High visibility within the field

- Retaining the copyright to your article

Submit your next manuscript at $\boldsymbol{\nabla}$ springeropen.com 